\title{
Filosofien korer derhen, hvor det brænder \\ - En introduktion til Odo Marquard
}

Den tyske filosof Odo Marquard fyldte i 2013 femogfirs år. I den anledning blev der på det tyske forlag Reclam, der gennem fire årtier har været Marquards faste forlag, udgivet to bøger: Dels bogen Der Einzelne. Vorlesungen zur Existenzphilosophie, der som titlen angiver er en forelæsningsrække om eksistensfilosofi, dels artikelsamlingen Endlichkeitsphilosophisches. Über das Altern, der samler en række tidligere udgivne essays om alderdom og endelighed. Hvor den første er atypisk i forhold til Marquards øvrige udgivelser ved at være en sammenhængende udfoldelse af ét bestemt tema - selvforholdet, som det fremtræder i lyset af især Heidegger og det tyvende århundredes eksistensfilosofi - er den sidstnævnte udgivelse typisk for Marquards produktion. Marquards forfatterskab består for hovedpartens vedkommende af lejlighedsvise samlinger af essays og artikler, ofte endda af omarbejdede foredrag, takketaler, mv. Hans filosofi er ikke af den slags, der udtrykker sig i systematisk sammenhængende værker, men snarere hvad man kunne kalde en lejlighedsvis, occasionel filosoferen. Det betyder ikke, at der ikke kan identificeres en række grundtemaer i Marquards filosofi. Tværtimod vil man nemt kunne få øje på en forholdsvis begrænset række af sådanne temaer, der til gengæld i de enkelte bøger varieres i det uendelige. Ikke uden grund er Marquards foretrukne form essayet, den forsøgsvise og fortsatte tilnærmelse til et emne, der som litterær og filosofisk genre står i modsætning til afhandlingen og dens krav om fuldstændighed og systematik.

\section{Endelighedens filosofi}

Også på en anden måde er bogen Endlichkeitsphilosophisches repræsentativ for Marquards filosofi. Netop den menneskelige endelighed udgør 
nemlig et af de grundtemaer, der i Marquards essayistiske filosofi bestandigt spindes nye tråde over. "Menneskelivet er kort", hedder det i teksten "Kleine Anthropologie der Zeit" fra bogen Individuum und Gewaltenteilung fra 2004, "vores eneste sikre fremtid er døden, vores mest uomgængelige fortid er fødslen” (Marquard 2004a: 9). Langt fra den abstrakte filosofiske og teologiske spekulations isørkner er begrebet om endeligheden næret af den konkrete og alment-menneskelige erfaring af tilværelsens forgængelighed og kontingens. Det er en eksplikation af det, Marquard selv kalder den vigtigste menneskelige tidserfaring: at vores livstid er knap, ja sågar "den knappeste af alle vore knappe resourcer" (Marquard 1994a: 48). Tiden har for det enkelte menneske altid karakter af frist, den løber ud, og vores liv er således, “hvor langt det end måtte være, kort”" (Marquard 1994a: 48).

At menneskets liv er endeligt - afgrænset til hver sin side af fødsel og død - betyder ifølge Marquard, at der er klare grænser for den menneskelige erkendelse og handlen. Ikke mindst sætter endeligheden grænser for de menneskelige forandringsbestræbelser, for vores forsøg på at forandre og forbedre på den verden, vi uforvarende fødes ind i, og som vi ligeså uforvarende igen må forlade. Fastholdelsen af endelighedens perspektiv fører på den ene side Marquard til skepticismen og den filosofiske hermeneutik - og til at forsvare hermeneutikken som skepticismens aktuelle form - på den anden side er den baggrund for hans opgør med erkendelsesidealet i den klassiske filosofi og for hans kritik af den moderne historiefilosofi. Men før vi kommer så langt - som en ikke uvæsentlig omvej til det væsentlige - en:

\section{Kort filosofisk biografi}

Heidegger har, i et forsøg på at forvise den biografiske betragtning fra filosofien, sagt, at der ikke er andet af relevans at sige om de omstændigheder, under hvilke en filosof levede, end at han blev født, levede og døde. Også for Marquard er fødsel og død afgørende livsomstændigheder - eller snarere livsbetingelser. Ikke desto mindre kan filosoffens liv, herunder hans tilknytningspunkter til samtidens filosofiske skoler og retninger, være af en vis betydning for forståelsen af hans filosofi, omend man ikke bør fortabe sig $\mathrm{i}$ indholdet af bibliotekskvitteringer og antallet af besøg hos den lokale konditor. 
Jeg vil derfor - før en egentlig karakteristik af Marquards filosofi give en kort skitse af hans filosofiske dannelseshistorie. Faktisk har Marquard selv stillet materiale til rådighed for en sådan i programskriftet "Abschied vom Prinzipiellen", som han i undertitlen kalder for "en autobiografisk indledning" (Marquard 1981a: 4).

Marquard er, som opmærksomme læsere vil have regnet ud, født i 1928, har altså endnu været barn, da nazisterne kom til magten i Tyskland i 1933 og fra elleve til sytten år i den skæbnesvangre periode fra 1939 til 1945. At erfaringerne under nazismen, hans unge alder til trods, har været afgørende for Marquard - som de har været det for de sidste tre-fire generationer i Tyskland - efterlader hans selvbiografiske indledning ingen tvivl om. Marquard refererer med tilslutning sociologen Helmuth Schelskys begreb om "den skeptiske generation", generationen født fra omkring 1930 til omkring 1940, som på samme tid måtte drage konsekvenserne af venstreradikalismens forlis og forsøge at klinke skårene efter den katastrofe, højreradikalismen bragte med sig (Marquard 1981a: 5-6). Dette skabte en generation, der både blev "mere virkelighedsnær [...], mere selvsikker" (erfolgssicherer) og på godt og ondt netop mere "skeptisk" end de forudgående generationer. Omend det naturligvis var de færreste, der som Marquard søgte tilflugt i den filosofiske skepsis, ser han selv en forklaring på sin filosofiske udvikling i tilhørsforholdet til netop denne generation (Marquard 1981a: 5-6).

Marquard begyndte i 1947 sit filosofistudium hos filosoffen Joachim Ritter, der på daværende tidspunkt var professor ved universitetet i Münster. Han promoverede i 1954 med en afhandling om Kants filosofi under vejledning af Max Müller ved Albert-Ludwigs-Universität i Freiburg. I årene 1955-1963 arbejdede han som videnskabelig assistent hos Ritter, af hvem han betragter sig selv som en uortodoks elev (Marquard 1981a: 7f.). Blandt de lærestykker, han - mere i form af 'indstillinger' end af 'teser' - har overtaget fra Ritter nævner Marquard "sansen for det historiske" og umuligheden af at "begynde forfra" (Marquard 1981a: 7), erkendelsen af, at det at "mærke" eller "fornemme" (Merken) er vigtigere end den logiske konsekvens og endelig indsigten $\mathrm{i}$ den menneskelige livserfarings nødvendighed for filosofien (Marquard 1981a: 7-8). ${ }^{1}$ Også Marquards forsvar for den moderne verden, hans defensorat for borgerligheden og hans kritik af den revolutionære emancipationstanke er stærkt influeret af Ritter (Jf. Marquard 2004d: 165). 


\section{Moderne skepsis}

Marquard betegner selv flere steder sin filosofi som en "endelighedens filosofi" (Philosophie der Endlichkeit) (f.eks. Marquard 1981a: 15; 2004b: 13-22). Hans tænkning fremhæver - som vi har set ovenfor - tidsfristen som et uomgængeligt menneskeligt vilkår, og den står som sådan i opposition til ethvert forsøg på at bortforklare det foreløbige og ufuldstændige ved den menneskelige erkendelse og handlen. Dette bringer den naturligt i forbindelse med den skeptiske tradition i filosofiens historie. Man kunne også - hvad Marquard ligeledes selv gør - kalde den for "endelighedsfilosofisk skepsis" (Marquard 2007a: 7), eller for skepsis på modernitetens betingelser. Det er nemlig ikke blot Marquards påstand, at den filosofiske skepsis er den filosofi, der mest kohærent svarer på endeligheden som grundvilkår, men ligeledes at det er den filosofi, der bedst svarer til de moderne eksistensbetingelser: "De egentligt moderne filosofier om det moderne er skeptiske filosofier" (Marquard 2007c: 53). Men hvad forstår Marquard ved skepsis?

En hyppigt genkommende formulering er, at skepsis er sansen for overbevisningernes magtdeling (jf. Marquard 1981a: 19; 2007c: 51). Når en sådan magtdeling er nødvendig, skyldes det, at ingen overbevisning - givet at overbevisninger altid er menneskelige overbevisninger og at mennesker ikke er absolutte, men endelige og fejlbarlige kan gøre krav på absolut gyldighed, men at overbevisningerne hver især har deres gyldighedsområde, inden for hvilket deres magtudøvelse er legitim. En skeptiker er i Marquards forstand ikke én, der ikke har nogen overbevisning, men én der har flere eller ligefrem "for mange" (Marquard 2007c: 51), dog under ingen omstændigheder en absolut. Skeptikeren ved, at livet er for kort til absolutte eller principielle sandheder, men han ved også, at overbevisningerne vokser frem af menneskets interaktion med verden som svampe af en skovbund. Ligeledes ved han, belært af den erfaring, historien og idéhistorien giver os, at overbevisninger sjældent er så beskedne, at de af sig selv og uden videre holder sig inden for et relativt gyldighedsområde. Netop derfor er en magtdeling mellem overbevisningerne påkrævet, og netop dette er skeptikerens funktion. Skepsis er som sansen for magtdeling også en kritik af enkelte overbevisningers despoti og $\mathrm{i}$ det hele taget af filosofiens ambition om at 
være en erkendelse af det hele. Skepticismen afviser "den principielle filosofi", der tror, den kan erkende virkelighedens grundlæggende årsager og principper, men den afviser ikke filosofien. Tværtimod forbliver den som kritik af den principielle filosofi selv filosofi, omend en uprincipiel af slagsen (jf. Marquard 1981a: 19).

Den skeptiske filosofi - eller rettere: de skeptiske filosofier, for skeptikeren kan naturligvis ikke holde sig til én - er ifølge Marquard det filosofiske udtryk for den holdning, der mest adækvat svarer til og på den moderne verden. Den moderne verden er - ifølge Marquard - den verden, i hvilken den ene og absolutte sandhed, levemåde, etc. må vige pladsen for de mange sandheder, de mange levemåder, etc. Hvad der i de gængse sociologiske modernitetsteorier optræder som individualisering er også altid pluralisering, "neutraliseringen af den ene og absolutte position" (die einzige absolute Position) (Marquard 2007c: 52). Derfor er den moderne "grundsans [...] sansen for magtdeling" og den moderne filosofi par excellence skepsis (Marquard 2007c: 53).

\section{Kritikken af historiefilosofien}

Marquards forsvar for den filosofiske skepsis som modernitetens filosofi fører ikke blot til en kritik af den klassiske metafysiske filosofi, der er absolut eller principiel i den forstand, at den søger efter en absolut erkendelse af de første principper, men den fører også til en kritik af det, han ser som den specifikt moderne absoluteringsfristelse: historiefilosofien og - en bestemt version af - idéen om historien som fremskridt. Hvad Marquard her er ude efter, er egentlig - mere end det er historiefilosofien som sådan - en bestemt historiefilosofi, og det, han er ude efter ved denne er, at den gør historien til noget bestemt: at den bliver monomytisk i stedet for polymytisk, idet den singulariserer de mange historier til én eneste (jf. Marquard 1981c). Frem for alt gælder kritikken diverse varianter af den marxistiske historiefilosofi, der ønsker at se historien som skueplads for den menneskelige frigørelse, for en fuldkommengorelse eller fuldendelse af mennesket. Historiefilosofien udgør en sekularisering af den filosofiske teodicé - et andet hovedtema i Marquards forfatterskab der relativerer den menneskelige ulykke og ufuldkommenhed under henvisning til en senere lykke og fuldkommenhed: "Den fuldendte 
histories finale lykkeverden helliger ulykken på de enkelte trin på vejen til deres [menneskenes, PJ] fuldkommengørelse" (Marquard 1995: 18). Idet den således singulariserer historien til den menneskelige frelsehistorie, der kulminerer $\mathrm{i}$ indretningen af "himlen på jorden", overser den imidlertid både, hvad mennesket er for et menneske, og hvad jorden er for en jord: Hverken "himlen på jorden" eller "helvede på jorden", men netop "jorden på jorden" (Marquard 1994c: 108; 2004b: 16).

Også historiefilosofien forsynder sig imod den menneskelige endelighed. Den er en "filosofi om menneskets absoluthed", og gør i sine konsekvenser mennesket til "den totale histories absolutte chef" (Marquard 2004b: 16). Mennesket er imidlertid netop ikke absolut, men det er - og vil altid være - et endeligt, begrænset og ufuldkomment væsen. Det viser de politiske radikalismers historie, der ifølge Marquard netop er historien om, at mennesket ikke kan bære den absolutte rolle, det tildeles af historiefilosofien og den radikaliserede emancipationstanke (Marquard 2004b: 16). Også historiefilosofien og de politiske radikalismers forlis peger derfor på nødvendigheden af en "endelighedens filosofi", der giver "endelige" - og ikke absolutte - svar på virkelighedens mangler og utilstrækkeligheder (Marquard 2004b: 16).

\section{Pluraliserende hermeneutik}

En sådan "endelighedens filosofi", der tager højde for, at mennesket hverken er eller nogensinde vil blive absolut, og at ikke mindst det moderne menneske vedvarende må leve i og forholde sig til flere konkurrerende virkeligheder og historier, finder Marquard i det 20. århundredes filosofiske hermeneutik. Marquard ser ikke blot som tidligere nævnt - sig selv som skeptiker, men specifikt som en "skeptiker af den hermeneutiske skole", og han betragter hermeneutikken som "den aktuelle form for skepsis" (die aktuelle Form der Skepsis) (Marquard 1981d: 117). Hermeneutik forstås og praktiseres af Marquard som pluraliserende hermeneutik, som en filosofi, der anerkender, at der ikke gives absolutte og endegyldige svar, men kun fortolkninger, og at heller ikke disse fortolkninger nogensinde vil være endegyldige. En sådan pluraliserende hermeneutik opstod som overlevelsesstrategi i det, Marquard kalder "borgerkrigen om den 
absolutte tekst" - striden om den definitive og "frelseabsolutte" udlægning af biblen - men dens betydning er ingenlunde begrænset hertil (Marquard 1981d: 128). Tværtimod viser den sig også i kampen mellem de historiefilosofiske og politiske totaliseringer som det pluralitetsvenlige og ikke-voldelige alternativ, ved hjælp af hvilket det moderne menneske kan komme overens med en virkelighed, der ikke er paradis på jorden, men jorden på jorden. Den moderne eller litterære hermeneutiks kerne er skepsis, fordi også den - som den filosofiske skepsis - er kendetegnet ved sansen for magtdeling, ved delingen "også af de magter, som historierne er, og ydermere også af de magter som teksterne er" (Marquard 1981d: 134). Hermeneutikken lærer det moderne menneske kunsten at leve i flere virkeligheder ad gangen og at balancere imellem forskellige og ofte modstridende sandheder og overbevisninger. Som pluraliserende hermeneutik står den både i modsætning til de oprindelige bibelske fortolkningslærer, der ikke helmede, før de sad inde med 'den absolutte tekst' - og hvis tilhængere af samme grund slog hinanden halvt fordærvede - og til den moderne historiefilosofis singulariserende hermeneutik (Marquard 1981d: 133). Den er et svar på den endelighed, der ligger i, at ikke blot mennesker, men også den betydning, de møblerer verden med, er forgængelig og til syvende og sidst forsvinder og dør bort (Marquard 1981d: 119-127).

\section{Forsvar for den moderne verden}

Marquards forsvar for det endelige individ og for den pluraliserende hermeneutik, der svarer på endeligheden ved at skåne og bevare, udtrykker sig politisk i et forsvar for den moderne - borgerlige - verden. Hans forsvar for magtdelingen gælder ikke blot i overført forstand som et forsvar for delingen af de divergerende overbevisninger og livsvirkeligheders magt, men også helt konkret som et forsvar for den politiske magtdeling, der etableres og institutionaliseres i det borgerlige samfund. Engagementet for individet må ligeledes være et engagement for den eneste verden, i hvilken dets selvbestemmelse og beskyttelsen af det mod vilkårlig magtudøvelse gælder som ret: den borgerlige verden (jf. Marquard 2004c: 93-96). Imod "de radikale verdensforbedreres" smag for det ekstraordinære, gælder det for en filosofi, der solidariserer sig med ende- 
ligheden om at tage parti for det ordinære. Den borgerlige verden er "ikke særligt ophidsende, en smule kedsommelig og i rigelig grad alt for menneskelig" (Marquard 2004c: 94), men den sikrer netop herigennem pluraliteten og den inddæmning af magten, der muliggør en udfoldelse af det individuelle liv $i$ al dets brogede mangfoldighed. Den er derfor til enhver tid at foretrække frem for de usikre revolutionseksperimenter, der i deres forsøg på at virkeliggøre den bedste af alle mulige verdener nemt kommer til at gøre den bestående endnu værre, end den i forvejen er. Til syvende og sidst vil hovedparten af de menneskelige livsomstændigheder - herunder ikke mindst den menneskelige endelighed - nemlig alligevel vedblive at være, hvad de alligevel var: Menneskets liv er - netop på grund af endeligheden - "altid for kort til, at det [mennesket] i vilkårligt omfang kan frigøre sig fra det gennem forandring: det har det ganske enkelt ikke tid til." Bevisbyrden hviler derfor ikke på den, der vil bevare, men på den der vil forandre (Marquard 1981a: 16). Konservatisme og borgerlighed - Marquard taler flere steder om det nødvendige mod til borgerlighed og om nødvendigheden af at satte sig til vagring mod vagringen (f.eks. Marquard 2004c; 2007b) - er i den forstand den naturlige konsekvens af den filosofiske besindelse på endeligheden og på menneskets fejlbarlige og ufuldkomne natur.

\section{Homo compensator}

Mennesket er endeligt. I det korte liv, det fører på jorden, er det ikke først og fremmest den, der fører, men den, der bliver ført. Ikke desto mindre må mennesket netop fore sit liv. Det er "af mangel på absoluthed en primær døgenigt, ${ }^{2}$ der sekundært bliver til homo compensator" (Marquard 2004b: 13). Som det hedder med en anden, for Marquard karakteristisk formulering, er mennesket det væsen, "der må gøre noget i stedet for" (Marquard 1981b: 37). I sig selv hverken absolut eller fuldkomment, må det lære at klare sig med andet og mindre. Det må kompensere. Det gælder ikke mindst i forholdet til den erkendelse, at det menneskelige livs ufuldkommenhed ikke er en accidentialitet, der kan overvindes gennem individuel anstrengelse eller historisk handlen, men derimod er noget, der vasentligt hører dette liv til. Den menneskelige lykke er altid "lykke i ulykken", det vil sige den er "relativeret ulykke." (Marquard 1995: 
13). Marquard trækker i sin kompensationsantropologi på Arnold Gehlens teori om mennesket som 'mangelvæsen', såvel som på kompensationsbegrebet hos Joachim Ritter.

At mennesket er det væsen, der må kompensere eller gøre noget andet i stedet for, gælder hos Marquard i flere betydninger. Det moderne menneske må, i en verden, der accelererer ved stadig højere hast, kompensere gennem traditionspleje og langsomhedskultur (Marquard 1994a: 52ff.); det kompenserer for den videnskabelige "affortryllelse" af verden gennem "det æstetiskes [...] erstatningsfortryllelse" (Marquard 2004b: 18); det lidende menneske kompenserer for ulykken ved at aftvinge denne en lykke $i$ - det vil sige på trods af eller igennem - ulykken (Marquard 1995: 30f.). Også kompensationen er - som hermeneutikken og den filosofiske skepsis - et svar på den menneskelige endelighed. Omvendt er både skepsis og hermeneutik at betragte som filosofiske kompensationsforsøg. Hver for sig svarer de på det, der udgør ikke blot det moderne menneskes drama og grundlæggende dilemma: det at måtte nojes med mindre.

\section{Om "Forsvar for evnen til at være ensom"}

"Forsvar for evnen til at være ensom", der hermed for første gang foreligger på dansk, forener en stor del af de ovenfor nævnte grundmotiver i Marquards filosofi. Også denne tekst handler om nødvendigheden af at kompensere - i dette tilfælde om at kompensere for ensomheden som grundvilkår ved at lære at erfare ensomheden positivt - og også denne tekst er i sin form et stykke pluraliserende hermeneutik: én blandt flere udlægninger af menneskets vilkår i den moderne verden. Teksten stammer oprindeligt fra samlingen Skepsis und Zustimmung. Philosophische Studien fra 1994 og den har første gang været holdt som radioforedrag på Sender Freies Berlin 1983.

Marquard har i et interview sagt, at filosofien har det til fælles med det frivillige brandvæsen, at den kører derhen, hvor det brænder. Filosofien har med andre ord kun sin berettigelse, for så vidt den bidrager til løsningen af det, man med Marquards filosofkollega Peter Sloterdijk kunne kalde for brandende livsproblemer, og som i den akademiske diskurs ellers alt for ofte neutraliseres til noget, der "kan behandles inden for rammerne af et smerteløst kollo- 
quialt arrangement.” (Rötzer 1987: 253). Ambitionen om at tage fat på sådanne problemer og slå ned på den moderne tilværelses ømme punkter kendetegner om noget den her foreliggende tekst. Marquard behandler i "Forsvar for evnen til at være ensom" den stigende ensomhed i det moderne samfund, især i de moderne storbyer. Selvom teksten er både stilistisk og tankemæssigt elegant, er der ikke tale om noget forsøg på at bortforklare, hvad der faktisk er - konkrete, eksistentielle - problemer. Tværtimod kaster Marquard gennem en række perspektivrige idéhistoriske analyser et forfriskende nyt lys på disse, og viser, at det moderne menneskes problem ikke så meget er ensomheden selv som det er den manglende evne til at leve $i$ og med den ensomhed, der - også og netop i det moderne samfund - er uundgå lig.

Teksten er bygget op i fire afsnit: I det første afsnit, der har titlen "Moderne ensomhed", sammenfatter Marquard de forskellige sociologiske og psykologiske analyser af ensomhedsepidemien i de moderne massesamfund. Marquard ønsker som sagt ikke at bortforklare problemet, men han tilslutter sig selv den tese, at den moderne tidsalder er "ensomhedens tidsalder." Det andet afsnit diskuterer under titlen "Symptomatiske modselskabeligheder" de forskellige måder, hvorpå det moderne menneske forsøger at fygte fra ensomheden. Eksempler på sådanne flugtforsøg er erstatningen af nærkommunikation med fjernkommunikation - en pointe der ikke er blevet mindre relevant $\mathrm{i}$ internettets tidsalder - og diverse former for gruppeidentifikation. I tredje afsnit, der har titlen "Behovet for ensomhed", søger Marquard at relativere påstanden om ensomheden som et onde ved at henvise til et menneskeligt ensomhedsbehov, der er lige så oprindeligt og påtrængende som behovet for socialitet. Ensomhed søger og behøver - således Marquard - skeptikere og videnskabsmænd, ja netop: mennesker, for så vidt disse endnu ikke identificerer sig fuldstændigt med de moderne samfunds tvang til selskabelighed. Endelig tegner Marquard i det sidste og fjerde afsnit under overskriften "kultivering af ensomheden" konturerne af en positiv erfaring af og omgang med ensomheden. Er mennesket således nok på den ene side "det dødelighedsbetingede ensomme levevæsen" er det ligeledes på den anden side det væsen, der kan kompensere for ensomheden ved at opdyrke og kultivere evnen til at vare ensom. Det kan - som i alle tilfælde - også i tilfælde af ensomhed gore noget andet $i$ stedet for. 


\section{Noter}

1 Se også interviewet med Marquard i Florian Rötzer (red.): Denken, das an der Zeit ist, s. 197.

2 Ty. "Taugenichts"; en døgenigt, en, der ikke dur til noget.

\section{Litteratur}

Marquard, Odo (1981a): "Abschied vom Prinzipiellen. Auch eine autobiographische Einleitung" i Abschied vom Prinzipiellen. Philosophische Studien, Stuttgart: Reclam.

Marquard, Odo (1981b): ’Inkompentenzkompensationskompetenz? Über Kompetenz und Inkompetenz der Philosophie“ i Abschied vom Prinzipiellen. Philosophische Studien, Stuttgart: Reclam.

Marquard, Odo (1981c): "Lob des Polytheismus. Über Monomythie und Polymythie“ i Abschied vom Prinzipiellen. Philosophische Studien, Stuttgart: Reclam.

Marquard, Odo (1981d): "Frage nach der Frage, auf die die Hermeneutik die Antwort ist" i Abschied vom Prinzipiellen. Philosophische Studien, Stuttgart: Reclam.

Marquard, Odo (1994a): "Zeit und Endlichkeit" i Skepsis und Zustimmung. Philosophische Studien, Stuttgart: Reclam.

Marquard, Odo (1994b): "Medizinerfolg und Medizinkritik. Die modernen Menschen als Prinzessinnen auf der Erbse“ i Skepsis und Zustimmung. Philosophische Studien, Stuttgart: Reclam.

Marquard, Odo (1995): "Glück im Unglück. Zur Theorie des indirekten Glücks zwischen Theodizee und Geschichtsphilosophie“ i Glück im Unglïck. Philosophische Überlegungen, Stuttgart: Reclam.

Marquard, Odo (2004a): "Kleine Anthropologie der Zeit" i Individuum und Gewaltenteilung. Philosophische Studien, Stuttgart: Reclam.

Marquard, Odo (2004b): "Skepsis als Philosophie der Endlichkeit" i Individuum und Gewaltenteilung. Philosophische Studien, Stuttgart: Reclam.

Marquard, Odo (2004c): "Mut zur Bürgerlichkeit. Vernünftig ist, wer den Ausnahmezustand vermeidet" i Individuum und Gewaltenteilung. Philosophische Studien, Stuttgart: Reclam.

Marquard, Odo (2004d): 'Eine Philosophie der Bürgerlichkeit. Joachim Ritters Hermeneutik der positivierten Entzweiung“" i Individuum und Gewaltenteilung. Philosophische Studien, Stuttgart: Reclam.

Marquard, Odo (2007a): "Vorbemerkung" i Skepsis in der Moderne. Philosophische Studien, Stuttgart: Reclam. 
Marquard, Odo (2007b): "“Ich bin ein Weigerungsverweigerer". Ein Gespräch mit Odo Marquard. Die Fragen stellte Jens Hacke“ i Skepsis in der Moderne. Philosophische Studien, Stuttgart: Reclam.

Marquard, Odo (2007c): "Skepsis in der Moderne. Überlegungen im Blich auf Heinrich Heine“ i Skepsis in der Moderne. Philosophische Studien, Stuttgart: Reclam.

Rötzer, Florian (1987): Denken, das an der Zeit ist, Frankfurt/Main: Suhrkamp. 